\title{
Efficacy of Instructional Program on Clinical Nurse Educators Implementation of Cooperative Learning at Faculty of Nursing
}

\author{
Asmaa H. Wanas', Seham E. Hamoda', Safaa A. Zahran ${ }^{3}$, Heba K. Obied ${ }^{4}$ \\ ${ }^{1}$ Assistant Lecturer of Nursing Service Administration, Faculty of Nursing, Tanta University. \\ ${ }^{2}$ Professor, of Nursing Service Administration, Faculty of Nursing, Tanta University. \\ ${ }^{3,4}$ Assistant Professor, of Nursing Service Administration, Faculty of Nursing, Tanta \\ University.
}

\section{Abstract:}

Background: Cooperative learning plays a vital role to equip the nursing students with overall needed qualities and skills that suggest clear adoption and effective implementation from clinical nurse educators. Aim: To determine efficacy of instructional program on clinical nurse educators' implementation of cooperative learning at Faculty of Nursing. Subjects and method: A quasi experimental study design was used. Setting: Study was conducted at Faculty of Nursing, Tanta University including all seven academic nursing departments. Subjects: All available $(\mathrm{n}=80)$ clinical nurse educators included nursing demonstrators and assistant lecturers enrolled at Faculty of Nursing, Tanta University. Three tools were used; Tool I: Clinical nurse educators' perception regarding cooperative learning implementation Questionnaire. Tool II: Knowledge questionnaire about cooperative learning implementation. Tool III: Cooperative learning implementation observational checklist. Results: Pre-instructional program, majority $(83.7 \%)$ of clinical nurse educators had low perception level regarding cooperative learning implementation. Majority $(88.7 \%)$ of clinical nurse educators had poor knowledge level preinstructional program, while post-instructional program high percent $(77.5 \%)$ of them had good knowledge level and $96.0 \%$ of them showed good practice level. Conclusion: Postinstructional program most of clinical nurse educators had good knowledge level with significant improvement compared to pre-instructional program. Also, majority of them showed good practice level regarding implementation of cooperative learning in clinical sessions. Recommendations: Conduct in-service training programs and workshops for qualifying and encouraging clinical nurse educators for using cooperative learning in their clinical sessions.

Key words: Clinical nurse educators, Cooperative learning, Nursing education. 


\section{Introduction}

Ever-changing and complex health care environment including serious diseases, complicated equipment, staffing shortage and globalization requires nursing graduates with specific intellectual and social skills to adapt and fulfill their growing roles and responsibilities ${ }^{(1,2)}$. The primary goal of nursing education is to prepare nursing professionals which are effective communicators, managers, producers of knowledge, critical thinkers, decision makers, and team workers for the benefit of patients and health care work environment as a whole. To cope with these challenging demands the nursing education reform is recommended for including more active and creative teaching strategies for qualifying more professional nursing graduates ${ }^{(1,3)}$.

Nursing education consists of theoretical and practical learning experiences to aid the nursing students acquiring the needed knowledge, skills, and attitudes for providing nursing care. A big section of nursing education is conducted in clinical environment. Clinical education provides opportunities for the nursing students to develop their skills, socialize to nursing profession and relieve gap between theory and practice. So that, clinical education is considered the heart of the nursing education program that put a major responsibility on clinical nurse educators for nursing education reformation ${ }^{(4,5)}$.

Clinical nurse educators are considered the most important factor in achieving clinical outcomes and assisting the nursing students to a quire the needed knowledge, skills and attitudes necessary for professional nursing practice. So that, clinical nurse educators' core competencies should include abilities to design, implement, and evaluate more innovative educational strategies to enhance nursing students' active involvement in learning process and producing highly qualified nursing students able to cope with work life and market demands ${ }^{(6,7)}$. Cooperative learning becomes one of the most remarkable areas of research and practice in nursing education. It can help to generate health care quality by providing opportunities for the nursing students to learn and practice collaboration, problem solving, critical thinking and interpersonal skills ${ }^{(1,8)}$.

Cooperative learning is a teaching pedagogy in which the nursing students work in small groups on a certain topic or an activity to enhance each other learning and accomplish common goals ${ }^{(9)}$. In cooperative activities, the nursing students play the most important role in 
understanding concepts and helping one another to learn the academic material. While, the clinical nurse educators' role changes from being a knowledge transmitter to be facilitators and mediators of learning process, design the learning context and prepare an appropriate class room environment for maximum cooperative learning implementation effectiveness ${ }^{(10)}$.

Cooperative learning implementation includes five essential features are critical to ensure its effectiveness and can discriminate it from other group work techniques including positive interdependence, where group members' success depends on actions of each group member that oblige them to use promotive interaction to achieve group goals ${ }^{(11)}$. Also, group members should held accountability for doing their share of the work, develop and practice social and collaborative skills including trustbuilding, leadership, decision-making and group self-evaluation for processing cooperative learning experience ${ }^{(12)}$.

Various benefits of cooperative learning can affect positively on both the nursing students and clinical nurse educators. Cooperative learning provide opportunity for the nursing students to work with their peers from different academic levels, sharing their understandings and opinions for solving problems that can enhance their academic achievements, self- confidence and self-esteem from being involved actively in the learning process and also, holding decision making and communication skills. Therefore, the nursing students become better prepared to perform more effectively in an interdependent and complex work environment (13). For clinical nurse educators, cooperative learning can enable them to shift practice from traditional teaching strategies to more active learning context and to be in alignment with the constructivist educational paradigm ${ }^{(14)}$.

Despite the great benefits of cooperative learning implementation for both clinical nurse educators and the nursing students, its implementation in clinical college classroom still a challenge. Effective cooperative learning implementation requires clinical nurse educators' clear understanding of its theoretical foundations, basic features and overcoming techniques of implementation barriers including limited time, insufficient resources and inadequate nursing students' social skills ${ }^{(13,15)}$. Faculty development programs including workshops and training programs on cooperative learning can play a vital role in adequately preparation of clinical nurse educators with the required knowledge and skills to teach and practice cooperative learning for the 
nursing students and prepare them for the collaborative practice ${ }^{(16)}$.

\section{Significance of the study:}

The latest multiple changes in nursing education including focusing more on developing the nursing students' problem solving, decision making, and collaborative skills that change clinical nurse educators' role to be more centered on clinical applications and teaching professional collaboration among nursing students. Based on these changes, there is a great need to equip clinical nurse educators with the needed competencies including knowledge and skills to contribute effectively through involving active learning strategies including cooperative learning to relieve gab between theory and practice and graduating highly effective and skilled nurses ${ }^{(17)}$. So that, conducting instructional program about cooperative learning implementation is very important for clinical nurse educators to adopt and effectively implement it in their clinical sessions for achieving the benefits for the nursing students and health care world as a whole.

\section{Aim of the study to:}

Determine efficacy of instructional program on clinical nurse educators' implementation of cooperative learning at Faculty of Nursing.

\section{Research hypothesis:}

Cooperative learning instructional program is expected to improve clinical nurse educators' knowledge and practice regarding its implementation.

\section{Subject and method}

\section{Study design:}

Quasi experimental study design was utilized to accomplish aim of the present study. It is well suited study design to determine the impact of an intervention on its target population ${ }^{(18)}$.

\section{Setting:}

The present study was conducted at Tanta University, Faculty of Nursing that structured at 1982 as High Institute of Nursing after this, formally transformed to Faculty of Nursing at 2000 and was gained accreditation at 2019. Seven academic nursing departments are enrolled in Nursing Faculty including Pediatric Nursing, Maternal and Newborn Health Nursing, Community Health Nursing, Psychiatric and Mental Health Nursing, Nursing Services Administration, Medical Surgical Nursing and Critical Care and Emergency Nursing.

\section{Subjects:}

All available $(n=80)$ clinical nurse educators included Nursing Demonstrators $(n=51)$ and Assistant Lecturers $(\mathrm{No}=29)$ enrolled at Tanta University, Faculty of Nursing. 


\section{Tools of data collection:}

Three tools were used to accomplish aim of this study including:

\section{Tool I: Clinical Nurse Educators'}

\section{Perception regarding Cooperative}

Learning Implementation in Clinical

Sessions Questionnaire.

This tool was developed by the researcher guided by George (2017) ${ }^{(19)}$, Shahzada et al, (2012) (20) and other recent related literatures ${ }^{(21,22)}$ to assess clinical nurse educators' perception regarding cooperative learning implementation in clinical sessions. It included three parts as follows:

Part (1): Clinical nurse educators' personal characteristics such as age, gender, academic position, years of experience, department and range of clinical group.

Part (2): It included 16 items to assess clinical nurse educators' opinion regarding cooperative learning implementation in clinical sessions. These items were categorized into three subscales including;

- Frequency of cooperative learning implementation in clinical sessions (6item),

- Preference of cooperative learning implementation in clinical sessions (2 items),

- Training needs regarding cooperative learning implementation in clinical sessions (8 items).

\section{Scoring system:}

Responses of clinical nurse educators were measured using Likert Scale. (2) point Likert Scale for closed questions yes take score (1) and No take score (2). 3 and 4 point Likert Scale for multiple choice questions. Choice A take score (1), choice B take score (2), choice C take score (3) and choice D take score (4).

Part (3): It included 137 items to assess clinical nurse educators' perception regarding cooperative learning implementation in clinical sessions. These items were categorized into five subscales:

\section{Basic features of cooperative learning} subscale: It included 27 items divided as follows:

- Positive interdependence (6 items).

- Face to face promotive interaction (6 items).

- Individual accountability (5 items).

- Appropriate use of social skills (6 items).

- Group processing (4 items).

2. The Students' role in cooperative learning subscale: It Included 7 items.

3. Clinical nurse educators' role in cooperative learning subscale: It included 50 items divided as follows:

A. Clinical nurse educators' role in pre implementation phase included 33 items divided as follows:

- Specify instructional objectives (5 items). 
- Grouping technique (3 items).

- Arrange class room and group seating (3 items).

- Arrange materials (3 items).

- Group role and tasks (17 items).

- Specify desired behaviors (2 items).

B. Clinical nurse educators' role in implementation phase included 6 items.

C. Clinical nurse educators' role in post implementation phase included 11 items

\section{Advantages of cooperative learning} implementation subscale: It included 25 items divided as follows:

- Academic benefits (10 items).

- Social benefits (4 items).

- Psychological benefits (7 items).

- Assessment benefits (4 items).

5. Obstacles of cooperative learning implementation subscale: It included 28 items divided as follows:

A. Obstacles facing clinical nurse educators included: It included 16 items divided as follows:

- Training obstacles (3 items).

- Administration obstacles (4 items).

- Environmental obstacles (6 items).

- Timing obstacles (3 items).

B. Obstacles facing the students: It included 12 items.

\section{Scoring system:}

Responses of clinical nurse educators were measured in a three points Likert Scale: agree (3), neutral (2), disagree (1). Levels of clinical nurse educators' perception regarding cooperative learning implementation in clinical sessions were cut of point as follows:

- High perception level $>75 \%$

- Moderate perception level $60-75 \%$

- Low perception level $<60 \%$

\section{Tool II: Knowledge questionnaire about} Cooperative Learning Implementation.

This tool was developed by the researcher guided by Bhushan (2017) ${ }^{(23)}$ and other recent related literature ${ }^{(24)}$ to test clinical nurse educators' knowledge about cooperative learning implementation. It included two parts as follows:

Part (1): It included clinical nurse educators' personal characteristics such as age, gender, academic position, years of experience and department.

Part (2): It included knowledge questionnaire about cooperative learning implementation. It included (50) questions in the form of (20) questions true \& false and (30) questions multiple choice categorized as follows:

- Items related to cooperative learning concepts and its theoretical foundation included 9 questions.

- Items related to basic features of effective cooperative learning and forms of cooperative learning groups included 9 questions.

- Items related to cooperative learning models included 7 questions. 
- Items related to benefits of cooperative learning included 8 questions.

- Items related to role of the students, and clinical nurse educators in cooperative learning implementation included 9 questions.

- Items related to obstacles of cooperative learning implementation and overcoming techniques included 8 questions.

\section{Scoring system:}

Each question was taken score (1) for correct answer and (0) for wrong answer. Levels of clinical nurse educators' knowledge were cut of point as follows:

- Good knowledge level >75\%

- Fair knowledge level 60 - 75\%

- Poor knowledge level <60\%

\section{Tool III: Cooperative Learning}

\section{Implementation Observational Checklist}

This tool was developed by the researcher guided by Purther (2018) (25), George (2017) (19) and other recent related literature (24) to assess clinical nurse educators' actual practice of cooperative learning in clinical sessions. It included three parts as follows:

Part (1): It included clinical nurse educators' identification data such as department, date and time.

Part (2): It included cooperative learning implementation in clinical sessions observational checklist. It included three subscales about basic features of cooperative learning, clinical nurse educators' role in cooperative learning, and students' role in cooperative learning that were categorized into three phases as follows:

\section{A. Clinical nurse educators' role in pre} implementation phase: It included 35 items divided as follows:

- Prepare class room and materials (3 items).

- Specify instructional objectives (4 items).

- Grouping Techniques (5 items).

- Arrange group members seating and materials (4 items).

- Assign group roles and tasks (19 items).

B. Clinical nurse educators' role in implementation phase: It included 51 items divided as follows:

\section{Basic features of cooperative} learning: It included 25 items divided as follows:

- Positive interdependence (5 items).

- Face to face promotive interaction (6 items).

- Individual accountability (5 items).

- Appropriate use of social skills (6 items).

- Group processing (3 items).

2. The students' role in cooperative learning implementation: It included 7 items.

3. Clinical nurse educators' role during cooperative learning process: It included 10 items. 
C. Clinical nurse educators' role in post implementation phase: It included 9 items.

\section{Scoring system}

Clinical nurse educators' observation was measured on 3 points Likert Scale as follow: Done $=(2)$, Partially done $=(1)$, Not done $=(0)$. Levels of clinical nurse educators' practice were cut of point as follow:

- Good practice level >75\%

- Fair practice level 60 - 75\%

- Poor practice level <60\%

Part (3): It included 10 items for assessing clinical class rooms' appropriateness for effective cooperative learning implementation.

\section{Scoring system}

Class rooms' appropriateness observation was measured on 3 points Likert Scale as follow: Present $=(2)$, Partially present $=$ (1), Not present $=(0)$. Levels of clinical class rooms' appropriateness were cut of point as follows:

- $\quad$ Appropriate level $>75 \%$,

- Partially appropriate level 60 $75 \%$,

- $\quad$ Not appropriate Level $<60 \%$

\section{Method}

1. Official permission to carry out the study was obtained from faculty authorities.

2. Ethical consideration:

Vol. 22 No. 3 (Suppl), August 2021 a) Approval of ethical committee at Faculty of Nursing.

b) Informed consent was obtained from clinical nurse educators after explanation of the nature and the aim of the study.

c) Confidentiality and the privacy of data collection were taken into consideration.

3. Tool I, III was presented to a jury of seven experts in the area of specialty to check content validity of its items. The experts were one professor of nursing administration, Damanhur University. One Professor of Nursing Administration, Mansoura University. One Professor of Nursing Administration, Alexandria University. Five experts two Assistant Professor and three Lectures of Nursing Administration Tanta University, Faculty of Nursing. Responses of experts were presented in four points Likert Sscale as follows: strongly relevant $=4$, relevant $=3$, not relevant $=2$, strongly not relevant $=1$. Necessary modifications were done including calcifying and simplifying certain words, excluding certain questions and adding others. The content validity index value for tool I was $94.85 \%$ and for tool III was $96.43 \%$.

4. A pilot study was carried out on $(n=8)$ of clinical nurse educators for testing 
clarity and applicability of tools and they weren't excluded from the total study subjects for general benefit. The time taken for completing questionnaire items was 30 minutes..

5. Reliability of tools was tested using Cronbach's Alpha Coefficient Factor, its value was (0.965) for tool I and (0.800) for tool III.

6. Clinical nurse educators' perception regarding cooperative learning implementation in clinical sessions (tool I) was used to assess clinical nurse educators' perception regarding cooperative learning implementation in clinical sessions pre implementation of the instructional program.

7. Knowledge questionnaire about cooperative learning implementation (tool II) was used to test clinical nurse educators' knowledge about cooperative learning implementation pre and post implementation of the instructional program.

8. Cooperative learning implementation observational checklist (tool III) was used to assess clinical nurse educators' actual practice of cooperative learning in clinical sessions post implementation of the instructional program.

9. Data collection from August 2020 to January 2021.
10. Limitation of the study: Cooperative learning implementation observational checklist included only $(n=75)$ of clinical nurse educators. The five which excluded 2 of them were in doctoral exam, one was in sick leave and 2 were in maternity leave.

11. The instructional program was conducted in four phases as follows: assessment phase, planning of the instructional program phase, implementation of the instructional program phase, and finally evaluation phase.

\section{Phase I: Assessment}

Pre-implementation of the instructional program, a pre-test was given to assess clinical nurse educators' levels of knowledge regarding cooperative learning implementation through filling tool II. Also, clinical nurse educators' perception regarding cooperative learning was assessed through filling tool I.

\section{Phase II: Planning of the instructional program}

The instructional program construction started with determining the instructional general and specific objectives according to the assessed clinical nurse educators' knowledge and perception levels regarding cooperative learning implementation and a review of relevant recent literature ${ }^{(24)}$. 
Aim of the instructional program:

Determine efficacy of instructional program on clinical nurse educators' implementation of cooperative learning at Faculty of Nursing.

\section{General objectives of the instructional} program:

The instructional program helps clinical nurse educators to gain knowledge about cooperative learning implementation and also, be able to practice it effectively in clinical sessions at the end of the instructional program.

Specific objectives of the instructional program:

- Explain cooperative learning concepts and its theoretical foundation

- State and structure basic features of cooperative learning and forms of cooperative learning groups.

- Recognize and apply cooperative learning models

- Identify and creates benefits of cooperative learning

- Express and apply role of the nursing students and clinical nurse educators in cooperative learning implementation

- Enumerates obstacles of cooperative learning implementation and apply overcoming techniques

\section{Content of the instructional program}

After determining instructional program objectives, instructional program content was designed, and teaching methods were selected to enable clinical nurse educators to acquire both knowledge and practice about cooperative learning implementation. Six sessions were included in the instructional program:

- Session (1): Cooperative learning concepts and its theoretical foundation.

- Session (2): Basic features and forms of cooperative learning.

- Session (3): Cooperative learning models.

- Session (4): Benefits of cooperative learning.

- Session (5): Role of the nursing students, clinical nurse educators and faculty administration cooperative learning implementation.

- Session (6): Obstacles of cooperative learning implementation and overcoming techniques.

\section{Teaching and learning strategies}

Lecture, discussion, cooperative learning, brain storming demonstration and role play were teaching and learning strategies included and utilized in the instructional program.

\section{Teaching aids}

PowerPoint Presentation (PPT), handouts, and videos, were included and utilized as teaching aids in the instructional program. 
Phase III: Implementation of the instructional program

- The instructional program started by informing clinical nurse educators about its objectives and encouraging participation through using good relationships and informed consent.

- The present study involved 80 clinical nurse educators including (51) nursing demonstrators and (29) assistant lecturers in Faculty of Nursing, Tanta University. Clinical nurse educators were divided into (8) groups. The instructional program was implemented in form of (6) sessions, one session every day, $2 \mathrm{hr}$ of each session for 6 days. The sessions were held out of clinical time in breaks and after ending work time.

- Cooperative learning was one of the teaching and learning strategies that were utilized in holding instructional program for more qualifying clinical nurse educators for its effective implementation.

- The researcher begun by instructing each session objectives, giving a lecture about important points of each session then, clinical nurse educators were classified into groups of four members, each group determined its logo, each member held a role such as leader, recorder, monitor and checker.
- Simulated scenarios relevant to each session objectives are utilized for encouraging clinical nurse educators brainstorming and acting cooperatively as groups for giving answer.

\section{Phase IV: Evaluation of the instructional program}

The instructional program was evaluated to determine the extent to which the instructional program improves clinical nurse educators' levels of knowledge and practice regarding cooperative learning implementation through:

- Immediately post-implementation of the instructional program, post- test to assess clinical nurse educators' levels of knowledge regarding cooperative learning implementation was given (tool II).

- Observation was done to assess clinical nurse educators' levels of practice regarding cooperative learning implementation (tool III) follow up post-implementation of the instructional program.

\section{Statistical analysis of the data}

Data were fed to the computer and analyzed using IBM SPSS software package version 20.0. (Armonk, NY: IBM Corp) Qualitative data were described using number and percent. Quantitative data were described using range (minimum and maximum), mean and standard 
deviation. Significance of the obtained results was judged at the $5 \%$ level. The used tests were Marginal Homogeneity Test, Paired t-test, Monte Carlo correction and Pearson coefficient.

\section{Results}

Table (1): Represents clinical nurse educators' personal characteristics. The table revealed that high percent $(62.5 \%)$ of clinical nurse educators were at age group $25<30$ years, while $28.8 \%$ of them were at age group $30<35$ years with mean age $28.34 \pm 2.97$. Majority (96.2\%) of clinical nurse educators were females but, only 3.8 $\%$ of them were male. High percent $(63.7 \%)$ of clinical nurse educators were demonstrators and the rest $36.3 \%$ of them were assistant lecturers. Regarding years of experience, above half $(53.7 \%)$ of clinical nurse educators had $1<5$ years and almost one third $(33.8 \%)$ of them had $5<10$ years. According to work department, $22.5 \%$ of clinical nurse educators were from Maternal and Newborn Health Nursing department, while $16.3 \%$ and $15.0 \%$ of them were from Nursing Administration and Medical Surgical Nursing department, respectively.

Table (2): Illustrates clinical nurse educators' opinion about frequency of cooperative learning implementation in clinical sessions. It was clear from the table that over half $(60 \%)$ of clinical nurse educators didn't implement cooperative learning previously in their clinical sessions, while $40 \%$ of them implemented cooperative learning before. Regarding to clinical nurse educators whose implemented cooperative learning in their clinical sessions, around one third (37.5\% and $31.3 \%)$ of them implemented cooperative learning per-week and persemester, respectively. High percent $(43.8 \%$ and $40.5 \%)$ of clinical nurse educators who implemented cooperative learning were for the third academic year for more than one hour per session, respectively. Also, half (50.0\%) of clinical nurse educators preferred small group size from five to seven students and majority (75.0\%) of them showed that cooperative learning sometimes can be easily implemented in their clinical sessions.

Table (3): Represents clinical nurse educators' opinion about training needs regarding cooperative learning implementation. The table illustrated that majority $(81.2 \%)$ of clinical nurse educators weren't familiar with the different techniques of cooperative learning. Also, majority (86.2\%) of them didn't receive any training regarding cooperative learning. The only $13.8 \%$ of clinical nurse educators whose received cooperative learning training, high percent $(72.7 \%$ and $63.6 \%)$ of them received onetime training, in form of workshops, respectively. Also, over half $(63.6 \%$ and $54.5 \%$ ) of clinical nurse educators received 
training since months, outside nursing faculty, respectively. Also, the table mentions that high percent $(77.5 \%, 72.5 \%)$ of clinical nurse educators didn't read about the technical ways of cooperative learning before and also, they didn't previously participate with the others whose effectively utilized cooperative learning in their clinical sessions, respectively.

Figure (1): Shows total perception levels of clinical nurse educators regarding cooperative learning implementation in clinical sessions. Pre-instructional program. The figure illustrated that majority $(83.7 \%)$ of clinical nurse educators showed low perception level regarding cooperative learning implementation in clinical sessions pre- instructional program.

Table (4): Illustrates total knowledge levels and mean scores of clinical nurse educators about cooperative learning implementation pre and post-instructional program. The table revealed that majority $(88.7 \%)$ of clinical nurse educators had poor knowledge level pre-instructional program. But, post-instructional program, high percent $(77.5 \%)$ of them had good knowledge level with statistically significant difference at $(\mathrm{P}=0.001)$. Also, pre-instructional program clinical nurse educators' total knowledge mean score was $21.32 \pm 7.96$ which increased to 42.30 \pm 8.16 post-instructional program with statistically significant difference at $\mathrm{p}=$ $<0.001$.
Figure (2): Illustrates total practice levels of clinical nurse educators' implementation of cooperative learning in clinical sessions post-instructional program. The figure showed that none of clinical nurse educators showed poor practice level, but majority $(96.0 \%)$ of them showed good practice level regarding implementation of cooperative learning in clinical sessions post-instructional program.

Table (5): Reveals correlation between knowledge of clinical nurse educators about cooperative learning implementation and their total perception levels preinstructional program. As shown in the table, that there was statistically significant correlation between total knowledge levels of clinical nurse educators about cooperative learning implementation and their total perception levels $(r=0.290)$. There was statistically significant correlation between clinical nurse educators' knowledge on basic features of cooperative learning and benefits of cooperative learning and their total perception levels $(r=0.005$ and 0.027 ), respectively.

Table (6): Shows correlation between knowledge of clinical nurse educators about cooperative learning implementation and their total practice levels postinstructional program. The table revealed that there was no statistically significant correlation between clinical nurse 
educators' knowledge about cooperative

learning implementation and their total

practice levels $(r=0.081)$. 
Table (1): Clinical nurse educators' personal characteristics $(n=80)$

\begin{tabular}{|c|c|c|}
\hline \multirow{2}{*}{5} & \multicolumn{2}{|c|}{ Clinical nurse educators } \\
\hline & No. & $\%$ \\
\hline \multicolumn{3}{|l|}{ Age } \\
\hline$<25$ & 5 & 6.2 \\
\hline $25<30$ & 50 & 62.5 \\
\hline $30<35$ & 23 & 28.8 \\
\hline$\geq 35$ & 2 & 2.5 \\
\hline Min. - Max. & \multicolumn{2}{|c|}{$24.0-37.0$} \\
\hline Mean \pm SD & \multicolumn{2}{|c|}{$28.34 \pm 2.97$} \\
\hline \multicolumn{3}{|l|}{ Gender } \\
\hline Male & 3 & 3.8 \\
\hline Female & 77 & 96.2 \\
\hline \multicolumn{3}{|l|}{ Academic position } \\
\hline Demonstrator & 51 & 63.7 \\
\hline Assistant Lecturer & 29 & 36.3 \\
\hline \multicolumn{3}{|l|}{ Years of experience } \\
\hline $1<5$ & 43 & 53.7 \\
\hline $5<10$ & 27 & 33.8 \\
\hline$\geq 10$ & 10 & 12.5 \\
\hline Min. - Max. & \multicolumn{2}{|c|}{$1.0-13.0$} \\
\hline Mean \pm SD & \multicolumn{2}{|c|}{$4.89 \pm 3.44$} \\
\hline \multicolumn{3}{|l|}{ Work department } \\
\hline Pediatric Nursing & 11 & 13.7 \\
\hline Maternal and Newborn Health Nursing & 18 & 22.5 \\
\hline Community Health Nursing & 10 & 12.5 \\
\hline Psychiatric and Mental Health Nursing & 9 & 11.3 \\
\hline Nursing Administration & 13 & 16.3 \\
\hline Medical Surgical Nursing & 12 & 15.0 \\
\hline Critical Care and Emergency Nursing & 7 & 8.7 \\
\hline \multicolumn{3}{|l|}{ What is the range of your clinical group? } \\
\hline $0-10$ & 0 & 0.0 \\
\hline $11-20$ & 16 & 20.0 \\
\hline $21-30$ & 43 & 53.7 \\
\hline 31 or more & 21 & 26.3 \\
\hline
\end{tabular}


Table (2): Clinical nurse educators' opinion about frequency of cooperative learning implementation in clinical sessions $(n=80)$

\begin{tabular}{|c|c|c|}
\hline \multirow[t]{2}{*}{ Cooperative learning implementation in clinical sessions } & \multicolumn{2}{|c|}{$\begin{array}{l}\text { Clinical nurse } \\
\text { educators }\end{array}$} \\
\hline & No. & $\%$ \\
\hline \multicolumn{3}{|l|}{$\begin{array}{l}\text { Previous implementation of cooperative learning in clinical } \\
\text { sessions }\end{array}$} \\
\hline Yes & 32 & 40.0 \\
\hline No & 48 & 60.0 \\
\hline \multicolumn{3}{|l|}{$\begin{array}{l}\text { Times of cooperative learning implementation in clinical } \\
\text { sessions }\end{array}$} \\
\hline Per week & 12 & 37.5 \\
\hline Per month & 9 & 28.1 \\
\hline Per semester & 10 & 31.3 \\
\hline Per year & 1 & 3.1 \\
\hline \multicolumn{3}{|l|}{ Academic year of cooperative learning implementation } \\
\hline $1^{\text {st }}$ academic year & 3 & 9.4 \\
\hline $2^{\text {nd }}$ academic year & 4 & 12.5 \\
\hline $3^{\text {rd }}$ academic year & 14 & 43.8 \\
\hline $4^{\text {th }}$ academic year & 11 & 34.4 \\
\hline \multicolumn{3}{|l|}{ Time given for cooperative learning activities } \\
\hline More than1 hour & 13 & 40.5 \\
\hline 1 hour & 6 & 18.8 \\
\hline 30 minutes & 3 & 9.4 \\
\hline Less than 30 minutes & 10 & 31.3 \\
\hline \multicolumn{3}{|l|}{ The typical size used for cooperative learning groups } \\
\hline 2- 4 students & 7 & 21.9 \\
\hline 5- 7 students & 16 & 50.0 \\
\hline 8 or more students & 9 & 28.1 \\
\hline \multicolumn{3}{|l|}{$\begin{array}{l}\text { Cooperative learning can be easily implemented in clinical } \\
\text { sessions }\end{array}$} \\
\hline Usually & 8 & 25.0 \\
\hline Some times & 24 & 75.0 \\
\hline Never & 0 & 0.0 \\
\hline
\end{tabular}


Table (3): Clinical nurse educators' opinion about training needs regarding cooperative learning implementation $(n=80)$

\begin{tabular}{|c|c|c|}
\hline \multirow{2}{*}{$\begin{array}{l}\text { Training needs regarding cooperative learning } \\
\text { implementation }\end{array}$} & \multicolumn{2}{|c|}{ Clinical nurse educators } \\
\hline & No. & $\%$ \\
\hline \multicolumn{3}{|l|}{$\begin{array}{l}\text { Familiarity with different cooperative learning } \\
\text { techniques }\end{array}$} \\
\hline Yes & 15 & 18.8 \\
\hline No & 65 & 81.2 \\
\hline \multirow{2}{*}{\multicolumn{3}{|c|}{$\begin{array}{l}\text { Receiving any training regarding cooperative } \\
\text { learning (training programs and workshops) }\end{array}$}} \\
\hline & & \\
\hline Yes & 11 & 13.8 \\
\hline No & 69 & 86.2 \\
\hline \multicolumn{3}{|l|}{ If yes, mention $(\mathrm{n}=11)$} \\
\hline \multicolumn{3}{|l|}{ Frequency } \\
\hline One time & 8 & 72.7 \\
\hline Two times & 2 & 18.2 \\
\hline More & 1 & 9.1 \\
\hline \multicolumn{3}{|l|}{ Type } \\
\hline Workshop & 7 & 63.6 \\
\hline Program & 0 & 0.0 \\
\hline Lecture & 4 & 36.4 \\
\hline \multicolumn{3}{|l|}{ Where } \\
\hline Nursing Faculty & 5 & 45.5 \\
\hline Outside nursing faculty & 6 & 54.5 \\
\hline \multicolumn{3}{|l|}{ When } \\
\hline Months & 7 & 63.6 \\
\hline One year & 1 & 9.1 \\
\hline More & 3 & 27.3 \\
\hline \multicolumn{3}{|l|}{$\begin{array}{l}\text { Previous participation with others whose effectively } \\
\text { utilized cooperative learning in clinical sessions }\end{array}$} \\
\hline Yes & 22 & 27.5 \\
\hline No & 58 & 72.5 \\
\hline \multicolumn{3}{|l|}{$\begin{array}{l}\text { Reading about technical ways of cooperative } \\
\text { learning before }\end{array}$} \\
\hline Yes & 18 & 22.5 \\
\hline No & 62 & 77.5 \\
\hline
\end{tabular}




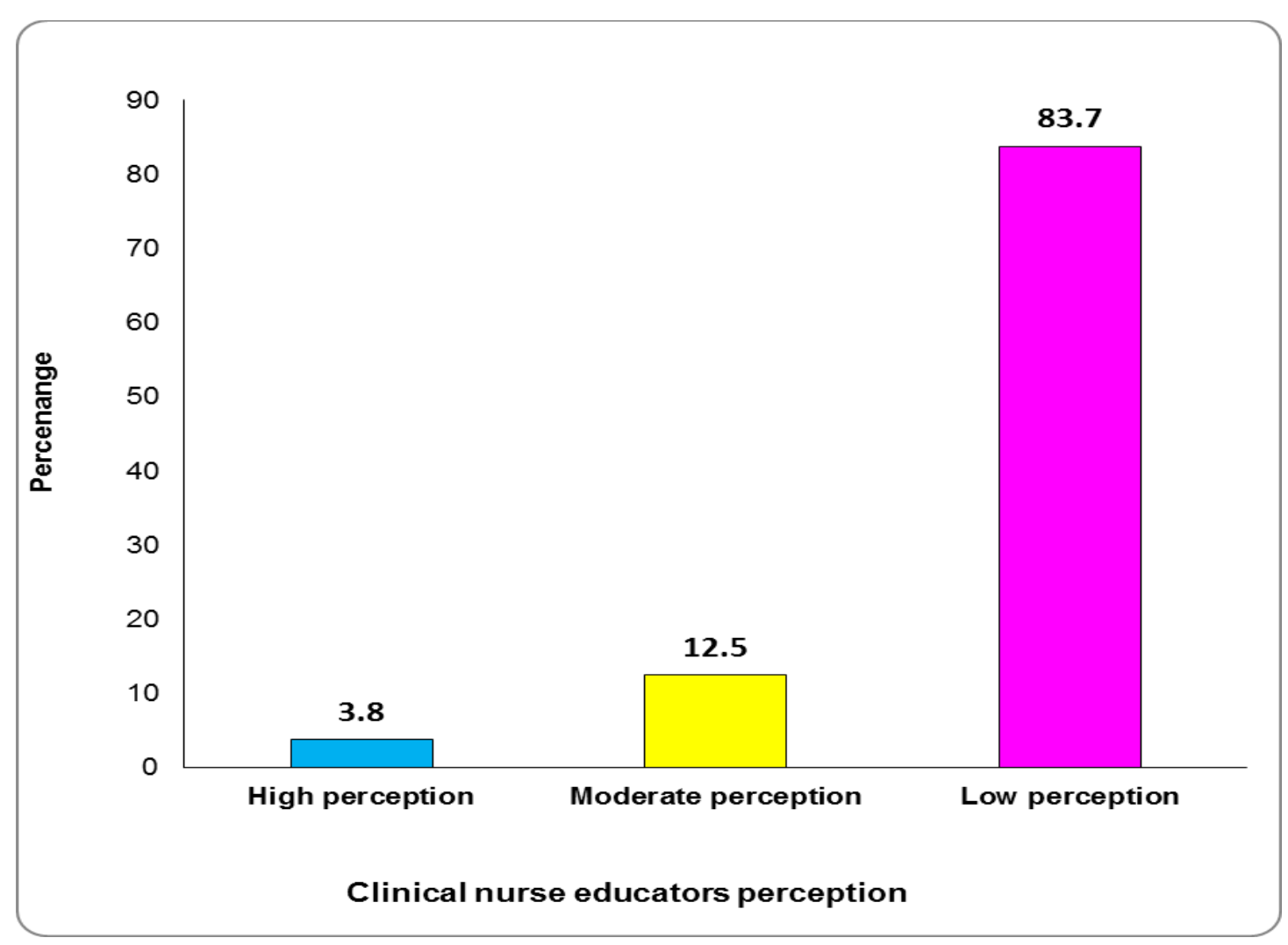

Figure (1): Total perception levels of clinical nurse educators regarding cooperative learning implementation in clinical sessions pre-instructional program $(n=80$

Table (4): Total knowledge levels and mean scores of clinical nurse educators about cooperative learning implementation pre and post-instructional program $(n=80)$

\begin{tabular}{|c|c|c|c|c|c|}
\hline \multirow{3}{*}{$\begin{array}{c}\text { Total } \\
\text { knowledge } \\
\text { levels }\end{array}$} & \multicolumn{4}{|c|}{$\begin{array}{l}\text { Clinical nurse educators } \\
(\mathbf{n = 8 0 )}\end{array}$} & \multirow{3}{*}{$\mathbf{P}$} \\
\hline & \multicolumn{2}{|c|}{ Pre } & \multicolumn{2}{|c|}{ post } & \\
\hline & No. & $\%$ & No. & $\%$ & \\
\hline \multirow{3}{*}{$\begin{array}{l}\text { - Good } \\
\text { - Fair } \\
\text { - Poor }\end{array}$} & 1 & 1.3 & 62 & 77.5 & \multirow{3}{*}{$<0.001^{*}$} \\
\hline & 8 & 10.0 & 15 & 18.7 & \\
\hline & 71 & 88.7 & 3 & 3.8 & \\
\hline $\begin{array}{l}\text { Min. - Max. } \\
\text { Mean } \pm \text { SD. }\end{array}$ & \multicolumn{2}{|c|}{$\begin{array}{c}0.0-40.0 \\
21.32 \pm 7.96\end{array}$} & \multicolumn{2}{|c|}{$\begin{array}{c}1.0-50.0 \\
42.30 \pm 8.16\end{array}$} & $\begin{array}{l}\mathrm{t}=19.465 * \\
\mathrm{p}=<0.001 *\end{array}$ \\
\hline
\end{tabular}

* Statistically significant at $\mathrm{p} \leq 0.05$ 


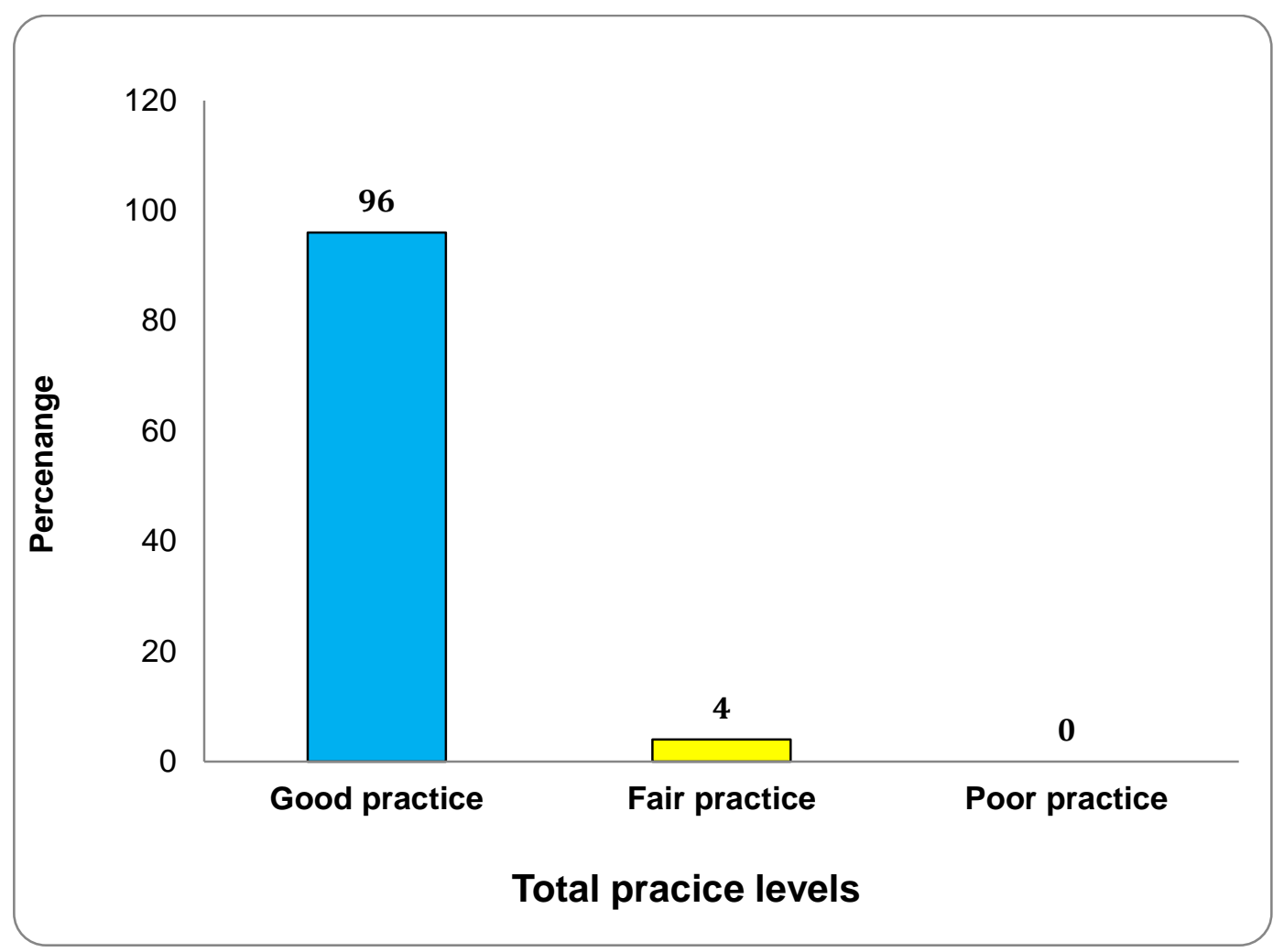

Figure (2): Total practice levels of clinical nurse educators' implementation of cooperative learning in clinical sessions post-instructional program $(n=75)$

Table (5): Correlation between knowledge of clinical nurse educators about cooperative learning implementation and their total perception level pre-instructional program $(\mathbf{n}=\mathbf{8 0})$

\begin{tabular}{|l|c|c|}
\hline \multirow{2}{*}{$\begin{array}{l}\text { Clinical nurse educators' } \\
\text { knowledge }\end{array}$} & \multicolumn{2}{|c|}{ Overall } \\
\cline { 2 - 3 } & $\mathbf{r}$ & $\mathbf{p}$ \\
\hline Basic features of cooperative learning & $0.314^{*}$ & $0.005^{*}$ \\
\hline Benefits of cooperative learning & $0.247^{*}$ & $0.027^{*}$ \\
\hline $\begin{array}{l}\text { Role of the students, and clinical } \\
\text { nurse educators in cooperative } \\
\text { learning implementation }\end{array}$ & 0.107 & 0.345 \\
\hline $\begin{array}{l}\text { Obstacles of cooperative learning } \\
\text { implementation }\end{array}$ & 0.109 & 0.336 \\
\hline \multicolumn{1}{|c|}{ Total } & $0.290^{*}$ & $0.009^{*}$ \\
\hline
\end{tabular}


Table (6): Correlation between knowledge levels of clinical nurse educators about cooperative learning implementation and their total practice levels post-instructional program $(n=75)$

\begin{tabular}{|l|c|c|}
\hline \multirow{2}{*}{$\begin{array}{l}\text { Clinical nurse educators' } \\
\text { knowledge }\end{array}$} & \multicolumn{2}{|c|}{ Overall practice } \\
\cline { 2 - 3 } & $\mathbf{r}$ & $\mathbf{p}$ \\
\hline $\begin{array}{l}\text { Basic features of cooperative } \\
\text { learning }\end{array}$ & 0.050 & 0.672 \\
\hline $\begin{array}{l}\text { Role of the students and clinical } \\
\text { nurse educators in cooperative } \\
\text { learning implementation }\end{array}$ & 0.053 & 0.649 \\
\hline \multicolumn{1}{|c|}{ Total } & 0.081 & 0.490 \\
\hline
\end{tabular}

* Statistically significant at $\mathrm{p} \leq 0.05$ 


\section{Discussion}

Results of the present study revealed that over half of clinical nurse educators had no previous implementation of cooperative learning in their clinical sessions. This may be due to cooperative learning implementation time constraints where over half of them agreed that cooperative learning preparation and implementation requires extra time and effort. Also, lack of environmental support including classrooms furniture doesn't permit face to face interaction, inadequate materials and modern technological media such as internet and data show. Additionally, lack of their knowledge and skills about effective cooperative learning implementation.

These findings were supported by Bristol et al. (2019) (26) who found that few nursing faculty members implemented cooperative learning and if it was used is blended with the lecture method that had occupied seventy five percent $5 \%$ of the lecture time. Also, Alias et al. (2018) ${ }^{(22)}$ found that high percent of the clinical educators reported that they didn't implement cooperative learning due to limited time and teaching aids constraints. Additionally, Saborit et al. (2016) (27) found that nursing educators' objection to cooperative learning implementation in their classes was imposed by curriculum organization, as well as their lack of knowledge and skills about effective implementation.

The results of the present study showed that more than one third of clinical nurse educators had implemented cooperative learning before once a time per week. This may be due to those clinical nurse educators may be used the traditional lecture method with a little time devoted to small group work without including all essential basic elements of formal cooperative learning for enhancing more students concentration and interesting. Also, accessible supportive environment that may not be available to all clinical nurse educators including space, time, and materials that could support them for implementing group work in their clinical sessions.

These findings were supported by Castillo (2017) ${ }^{(28)}$ who found that around half of clinical educators implemented cooperative learning in their courses ranging from informal to formal type. Also, one third of them reported using cooperative learning at least once a time per week. The others reported using cooperative learning at least once a time per class period and per semester. The educators whose implemented cooperative learning reported having environmental support and opportunities to learn than those didn't implement it. 
The present study results revealed that half of clinical nurse educators who implemented cooperative learning in their clinical sessions preferred small group size from five to seven students. This may be justified by small group members can creates more intimacy and familiarity among group members. They can communicate effectively with each other, each group member can participate that ensure good group work results.

These findings were supported by Koç (2018) (29) supported these findings who found that most of clinical educators indicated that they preferred to arrange their students in groups of fours and only one quarter of them indicated a preference of five members in each group. Also, Roh (2017) ${ }^{(30)}$ reported that group size was a significant factor affecting learner engagement in cooperative activities. Small groups' usage facilitated safe learning environment and the best practice concerning group size was four to six members. He concluded that simulation educators should consider an optimal group size for achieving learning outcome. Also, Akpolat (2016) (31) found that majority of pre service educators preferred small groups of four students or less in which group members have equal chance to participate and easy expression of their opinions freely compared to large groups of seven group members or more in which difficulty of self-expression in cooperative activities can occur. Additionally, Lama et al. (2015) ${ }^{(32)}$ found that small group teaching sessions were highly interactive and made both the educator and the students communicate effectively and greatly enhanced overall understanding of the students.

Results of the present study revealed that majority of clinical nurse educators didn't receive any training regarding cooperative learning. The few percent of clinical nurse educators who received training regarding cooperative learning, over half of them were outside nursing faculty. This may be interpreted by lack of nursing faculty administration conduction of orientation programs for clinical nurse educators about cooperative learning. Also, inadequate fund for supporting adequate preparation for cooperative learning implementation in clinical classrooms.

These finding were explained by Bilal et al. (2019) ${ }^{(16)}$, they indicated that faculty members are considered the main ingredients to enhance professional education. Faculty development programs play a crucial role in fostering faculty members' knowledge and skills in their teaching and learning process. But, structuring formal programs may not be available or limited, where organizing faculty development programs need identifying educators' educational needs, 
adequate resources, budget, administrative support, space, and also, well-structured theoretical framework.

Also, Berghout (2019) ${ }^{(33)}$ and Reid et al. (2018) ${ }^{(34)}$ found that most nurse educators did not formally learn or received any preparation or training about cooperative learning when they were students and continue to display this lack of understanding till now. So that, they become unmotivated to utilize cooperative learning with their undergraduate nursing students.

Results of the present study revealed that majority of clinical nurse educators showed low perception level regarding cooperative learning implementation in clinical sessions pre-instructional program. This can be explained by poor knowledge level of clinical nurse educators about cooperative learning implementation. Preinstructional program, perception level of clinical nurse educators was positively correlated significantly with their knowledge level about cooperative learning implementation.

Myers et al. (2019) ${ }^{(35)}$ supported these findings where found that majority of clinical instructors had low perception and experiences regarding collaborative clinical education pre conducting an academic program about cooperative learning and noted that they were in a strong need to be prepared with appropriate teaching strategies for elevation their low perception and experiences. Also, Saborit et al. (2016) (29) found that over half of clinical educators had low perception regarding cooperative learning implementation and explained that this could be related to the educators' scarce or ineffective training regarding cooperative learning strategies. Contradictly, Alias et al. (2018) ${ }^{(22)}$ found that the clinical educators had high perception level toward cooperative learning implementation and they were ready and felt confident to practice it although, the constraints were present including classroom control, time and limited teaching aids.

The current study findings showed that there was a statistical significant difference between clinical nurse educators' knowledge about cooperative learning implementation pre and postinstructional program. Pre- instructional program, majority of clinical nurse educators had poor knowledge level compared to high percent of them had good knowledge level post-instructional program. Pre-instructional program, knowledge deficiency of clinical nurse educators about cooperative learning implementation can be explained by inadequate of training programs and workshops regarding cooperative learning. Also, inadequate preparation of clinical 
nurse educators through reading about cooperative learning techniques or participation with those used cooperative learning in their clinical sessions before.

These findings were supported by Williamson (2021) ${ }^{(36)}$ who reported that cooperative learning implementation is not an easy approach that can be implemented quickly and easily. But, it requires fully knowledgeable dedicated staff and ongoing support for successful implementation. Also, he found that significantly increase in the knowledge and self-confidence of the nursing educators about cooperative learning implementation after his educational project compared to preeducational project.

Also, Keramati and Gillies (2021) (37) found that unfamiliarity and knowledge lack among Iranian faculty members regarding cooperative implementation. They indicated that faculty members starts the teaching profession and obtain teaching knowledge only through experience. So on, there is a need to design cooperative learning courses and workshops especially in their disciplines. Also, they concluded that their study made a significant development of faculty members' knowledge about cooperative learning through giving a clear message that good familiarity of cooperative learning can improves quality of its implementation.
In addition to, Huda (2020) ${ }^{(38)}$ who was interested with exploring knowledge and attitude of nursing educators about active learning strategies including cooperative learning in Pakistan reported that the nursing educators need to have adequate knowledge and skills to integrate cooperative learning in their educational process for improving nursing students problem solving and critical thinking skills. So that, training and developmental program for nursing educators can be proposed.

Adding to that the current study results revealed that there was statistically significant improvement of clinical nurse educators' knowledge levels on all cooperative learning implementation domains post-instructional program compared to pre-instructional program. This can be attributed by utilizing creative teaching approaches that facilitate clinical nurse educators learning process about cooperative learning implementation. Also, providing opportunities for them to apply the theoretical knowledge by working cooperatively on simulated scenarios through program sessions provides some of the realism on cooperative learning and reflected on more understanding and improving clinical nurse educators' knowledge about cooperative learning implementation. 
These findings were supported by Kimmelmann and Lang (2018) ${ }^{(39)}$, they found significant improvement in educators' knowledge on all cooperative learning domains after cooperative learning training programs though linking university educators from different institution and using blended learning course program. The university educators had opportunity to exchange their experiences and opinions. They gained multiple perspectives about cooperative learning, its benefits, and factors influencing its success after the training program.

\section{Also, Duran and Miquel (2017)}

(40)

conducted peer tutoring program about cooperative learning implementation through constructing collaborative network among clinical educators and the educational institution administration to use cooperative learning in their classrooms. They found positive effects of the educational programs on educators' learning on cooperative learning concepts and their roles to adjust the program to their educational context.

Results of the present study postinstructional program revealed that majority of clinical nurse educators showed good practice level regarding cooperative learning implementation in their clinical sessions post- instructional program. This can be explained by clinical nurse educators acquired sufficient knowledge about effective cooperative learning implementation. Also, creating cooperative learning environment for clinical nurse educators to exchange their knowledge with their peers on simulated scenarios about program sessions kept them played an active role. So, reflection occurs on improving their role practice in cooperative learning implementation phases including pre implementation, implementation and post implementation phase.

These findings were supported by Hebles et al. (2021) ${ }^{(41)}$, they found significant improvement of faculty members' application of several cooperative learning dimensions including lesson planning and tasks, structuring basic features, social, interdependence, reflection and evaluation after cooperative learning training program. Also, Ming (2018) ${ }^{(42)}$ found that successful cooperative learning implementation among nursing educators in Jamaica following cooperative learning training program. Also, the nursing educators showed positive attitude toward successful adoption of cooperative learning in their class rooms for more addition to, Goodyear (2016) (43) who found that implementing a development program on cooperative learning significantly supported clinical educators' practices of cooperative learning in their classrooms 
and adapted their practices of cooperative learning to their students' learning needs. Also, he indicated that continuous professional development is recommended for educators to learn and develop their practices to meet the complex and contemporary needs of their students.

The current study results showed that there was statistically significant correlation between clinical nurse educators' knowledge and perception about cooperative learning implementation preinstructional program. This can be explained by clinical nurse educators' ineffective training regarding novel teaching strategies including cooperative learning in their initial or during professional training in their nursing faculty. So, on this scarce training had a deceive influence on clinical nurse educators' perception.

These finding were supported by Saborit et al. (2016) ${ }^{(27)}$, found a significant correlation between clinical educators' knowledge about cooperative learning and their perception. They found that clinical educators whose adopted high perception levels regarding cooperative learning received training programs and knowledge about cooperative learning before.

The present study results revealed that that there was no statistically significant correlation between clinical nurse educators' knowledge and practice about cooperative learning implementation postinstructional program. This can be attributed by inappropriate class room environment for some clinical nurse educators including large class size, furniture isn't comfortable enough and fixed that partially hinder face to face interaction, inadequate enough space for students' interaction and movement. Also, limited time for clinical nurse educators. All of this can hinder them from successful practice of some cooperative learning implementation items.

These findings were supported by Moges (2019) ${ }^{(44)}$ who verified that there was no significant relation between clinical instructors' knowledge and practice about cooperative learning implementation. He reported that class room condition to implement cooperative learning appropriately wasn't good. Class room size was large, the desks and chairs were not easily movable. The classroom was crowded by chairs. He concluded class room appropriateness was the core challenges to implement cooperative learning effectively. Also, Saborit et al. (2016) ${ }^{(29)}$ indicated that clinical educators' knowledge about cooperative learning tends to play a key role in effective cooperative learning implementation. But, this is not often due to lack of interest, limited time for clinical educators can disturb effective cooperative learning 
implementation regardless training is present.

\section{Conclusion}

Clinical nurse educators included nursing demonstrators and assistant lecturers at Faculty of Nursing, Tanta University had low perception level and poor knowledge level regarding cooperative learning implementation in clinical sessions preinstructional program. Lack of clinical nurse educators' perception and knowledge regarding cooperative learning implementation indicated that they had a great need for an instructional program about cooperative learning implementation. Post-instructional program most of clinical nurse educators had good knowledge level with significant improvement compared to preinstructional program. Also, majority of them showed good practice level regarding implementation of cooperative learning in clinical sessions.

\section{Recommendations}

On the light of the findings of the present study, the following recommendations are suggested for:

\section{Faculty administrators:}

-Revise and reform nursing curriculum to be more student centered and in alignment with the constructivist educational paradigm.
-Encourage clinical nurse educators and nursing students to implement cooperative learning in clinical sessions.

-Provide an appropriate and supportive cooperative learning environment e.g. large classes, comfortable furniture, movable desks, data shows, pens, papers, books, and internet.

-Conduct in-service training programs and workshops for clinical nurse educators about cooperative learning implementation.

-Conduct orientation programs and allow mentors for novice clinical nurse educators for enhancing their educational selfcontrol.

- Conduct regular meetings with clinical nurse educators to share experiences and prepare cooperative exercises that save a lot of time and effort and facilitate implementation.

\section{Nursing educators:}

-Shift nursing education paradigm from traditional teaching methods to more student centered approaches including cooperative learning.

-Encourage nursing students' active involvement in collaborative activities through instruction about cooperative learning benefits.

-Develop nursing students' social and collaborative skills including communication, decision making, and 
conflict management for effective collaboration.

-Deign challenged cooperative activities including simulated scenarios for active engagement of the nursing students in collaborative process.

-Ensure fair grading methods including self-evaluation, peer-evaluation, and individual tests to enforce nursing students' collaboration.

\section{Further studies:}

-Additional studies should be conducted to assess clinical nurse educators' educational needs.

-The effectiveness of cooperative learning implementation on nursing students transition to health care work environment.

\section{References}

1. Karasu F, Arapaci R, Çopur E, Çam H. Cooperative learning model in nursing education. Journal of Inonu University Health Services Vocational School. 2020; 8 (3): 973-88.

2. Yang L, Jiang D, Nie H, Tang S. Research on the effect of cooperative learning model on nursing skills of practice nurses and standardized training of newly-recruited nurses. Journal of Biomedical Research. 2018; 29 (9): 1788-91.

3. Horton A. Nurse Educator Perceptions of Using Simulation for Evaluation of Nursing Competencies. Published Doctoral Thesis. College of Education,
Walden University, United

States, 2020. Available from: https://scholarworks.waldenu.edu/cgi/ viewcontent. cgi $?$ article $=10185 \&$ conte $\mathrm{xt}=$ dissertations

4. Torabizadeh C, Kalyani M, Jamshidi N, Molazem Z, Sharif F. The challenges of nursing students in the clinical learning environment: A qualitative study. Scientific World Journal. 2016; 2016 (1846178): 1-7.

5. Alammar K, Ahmad M, Almutairi S, Salem O. Nursing students' perception of the clinical learning environment. The Open Nursing Journal. 2020; 14 (1): 174-79.

6. Soroush A, Andaieshgar B, Vahdat A, Khatony A. The characteristics of an effective clinical instructor from the perspective of nursing students: A qualitative descriptive study in Iran. Journal BMC Nursing. 2021; 20(36): 1-9.

7. World Health Organization. Nurse Educator Core Competencies. 2016 Available from: https://www.who.int/ hrh/nursing_midwifery/nurse_educato r050416.pdf

8. Dhull P, Verma J. Jigsaw teaching technique for teaching science. International Journal of Research and Analytical Reviews (IJRAR). 2019; 6(2): 809- 15.

9. Villar T, Chordá V, Gasch A, TudelaD. Cooperative learning and 
hand disinfection in nursing students. Journal of Invest Educ. Enferm. 2018; 36 (2): 101-12.

10. Namaziandost E, Shatalebi V, Nasri M. The impact of cooperative learning on developing speaking ability and motivation toward learning English. Journal of Language and Education. 2019; 5 (2):83-101.

11. Cañabate D, Romeu M, Menció A, Nogué L, Planas M, Pla J. Crossdisciplinary analysis of cooperative learning dimensions based on higher education students' perceptions. Sustainability Journal. 2020; 12 (8156): 1-18.

12. Wongsasung J, Satityudhakarn S, Takan S, Nutong S. Effect of a cooperative learning module on nursing students' inquisitiveness in a Thai University. Catalyst Journal. 2018; 18 (1): 37-45.

13. Page A. Implementing cooperative learning: A consideration of barriers and enablers. Journal of Initial Teacher Inquiry. 2017; 3(1): 49-52.

14. Ukpepi B, Aglazor G, Odey C. Cooperative learning strategy as tool for classroom management. Advances in Multidisciplinary Research Journal. 2016; 2(2): 67-76.

15. Ghaith G. Teacher perceptions of the challenges of implementing concrete and conceptual cooperative learning.
Issues in Educational Research. 2018; 28(2): 385- 404.

16. Bilal S, Guraya S, Chen S. The impact and effectiveness of faculty development program in fostering the faculty's knowledge, skills, and professional competence: A systematic review and meta-analysis. Saudi Journal of Biological Sciences. 2019; 26 (1): 688-697.

17. Mannino J, Cotter E. Educating nursing students for practice in the 21st Century. International Archives of Nursing and Health Care. 2016; 2(1): 1-4.

18. Bärnighausen $T$, Røttingen $J$, Rockers P, Shemilt I, Tugwell P. Quasiexperimental study designs series: Uses and value. Journal of Clinical Epidemiology. 2017; 89(4): 21-29.

19. George R. Teacher Perception of Cooperative Learning Strategies Impacting English Learner Engagement and Academic Performance Levels. Published PHD Thesis, College of Education, Concordia University, Portland. 2017. Available from: https://commons. cuportland.edu/cgi/viewcontent.cgi?re ferer $=\&$ httpsr edir $=1 \&$ article $=1015 \&$ context=edudissertations.

20. Shahzada A, Valckeb M. Bahooc R. A study to analyze the teacher's perceptions about the adoption of 
collaborative learning in post-graduate classes of IUB. Social and Behavioral Sciences. 2012; 46 (1): $3056-59$.

21. Le H, Janssen J, Wubbels $T$. Collaborative learning practices: Teacher and student perceived obstacles to effective student collaboration. Cambridge Journal of Education. 2018; 48(1): 103-22.

22. Alias S, Hussin H, Hassan J. Perception of Teacher on Cooperative Learning. MATEC Web of Conferences. 2018; 150(05068): 1-4.

23. Bhushan A. Cooperative Learning. 2017. Available from: https://scholar. google.com.eg/scholar?cluster $=75153$ $06623152771453 \& \mathrm{hl}=$ en\&as_sdt $=0,5$ $\&$ scilib=1\&scioq=related:HCrEyJlwXkJ:scholar.google.com/.

24. Almulla M. An Investigation of Cooperative Learning in A Saudi High School: A Case Study on Teachers' and Students' Perceptions and Classroom Practices. Published PHD Thesis, University of Leicester, Saudi Arabia. 2017. Available from: https://lra.le.ac.uk/bitstream/2381/399 47/1/2017ALMULLAMPhD.pdf.

25. Purther C. High School Teachers and Cooperative Learning. Published PHD Thesis, Faculty of California, University of California, California, 2018. Available from: https://bronco scholar.library.cpp.edu/bitstream/hand
le/10211.3/204207/PurtherCarlo_Diss ertation2018.pdf? sequence $=1$

26. Bristol T, Hagler $\mathrm{D}$, Bohler $\mathrm{J}$, Wermers R. Nurse educators' use of lecture and active learning. Teaching and Learning in Nursing. 2019; 14 (1): 94-96.

27. Saborit J, Río J, Estrada J, Gimenez A, Alonso A. Teachers' attitude and perception towards cooperative learning implementation: Influence of continuing training. Teaching and Teacher Education Journal. 2016; 59 (1): 438-45.

28. Castillo A. Understanding Two Year College Mathematics Faculty Perceptions and Use of Cooperative Learning. Published PHD Thesis. Faculty of the Graduate. University of Texas, Austin, 2017. Available from:

29. Koç E. Exploring collaborative learning with a focus on group activities in EFL classrooms. Journal of the Faculty of Education. 2018; 19(3): 582-597.

30. Roh Y. Survey of factors influencing learner engagement with simulation debriefing among nursing students. Nursing Health Science. 2017; 19 (1): 485-91.

31. Akpolat E. Perceptions of EFL PreService Teachers about Cooperative Learning: A Case Study in a State University in Turkey. Published 
Master Thesis. College of Foreign Language Education. Middle East Technical University, Turkey, 2016. 39-42. Available from: https:// etd.lib.metu.edu.tr/ upload/12619729/ index.pdf

32. Lama P, Kulkarni J, Tamang B, Sinha P. The impact and significance of small and large group teaching and learning in medical curriculum. SMU Medical Journal. 2015; 2(2): 175-183.

33. Berghout T. Undergraduate Nurse Educator Perceptions of Preparation to Teach Inter-professional Colla boration. Published PHD Thesis. College of Education, Walden University, United States. 2019. Availble from: https://scholarworks. waldenu.edu/cgi/viewcontent.cgi?artic $\mathrm{le}=8804 \&$ contex $\mathrm{t}=$ dissertations

34. Reid A, Fielden S, Holt J, MacLean J, Quinton N. Learning from interprofessional education: A cautionary tale. Journal of Nurse Education Today. 2018; 69 (1): 128 -33.

35. Myers K, Davis A, Thomas S, Bilyue C. Clinical instructor perceptions of the collaborative clinical education model: Providing solutions for success in physical therapy education. Internet Journal of Allied Health Sciences and Practice. 2019; 17 (4): 1-12.

36. Williamson G. Collaborative learning in practice: Videos to prepare students and staff. Journal of Nursing Times. 2021; 117 (3): 49-51.

37. Keramati M, Gillies R. Constraints of cooperative learning. Iranian Journal of Comparative Education. 2021; 4(1): 958-72

38. Huda S. Teaching Methodologies in Nursing Education. 2018. Available from: https://nursinganswers.net/ essays/teaching-methodologiesnursing-5033.php?vref=1

39. Kimmelmann N, Lang J. Linkage within teacher education: Cooperative learning of teachers and student teachers. European Journal of Teacher Education. 2019; 42(1): 52-64 .

40. Duran D, Miquel E. Peer learning network: Implementing and sustaining cooperative learning by teacher collaboration. Journal of Education for Teaching. 2017; 43(3): 349-60.

41. Hebles M, -Eulate C, Santos M, Gallego L. Towards a cooperative learning environment in universities through in-service training. Sustainability Journal. 2021; 13(1112): 1-17.

42. Ming $H$. Implementing cooperative learning in the nursing staff development program at an urban hospital in Jamaica. Nursing and Care Journal. 2018; 7 (1):110- 15.

43. Goodyear V. Sustained professional development on cooperative learning: Impact on six teachers' practices and students' learning. 2017; 88(1): 83-94.

44. Moges B. Practices and challenges of cooperative learning in selected College of ARIS University: As a motivational factor on enhancing students' learning. Universal Journal of Psychology. 2019; 7(1): 1-17 